\title{
UV-A Activated ZnO Mediated Photocatalytic Decolorization of Nigrosine (Acid Black 2) Dye in Aqueous Solution
}

\author{
Mohammed Thamer Jaafar \\ Department of Petroleum \& Petrochemical Engineering, College of Engineering, Kerbala University, Kerbala, Iraq \\ Email:dr.mohammedthamer@yahoo.com
}

How to cite this paper: Jaafar, M.T. (2017) UV-A Activated ZnO Mediated Photocatalytic Decolorization of Nigrosine (Acid Black 2) Dye in Aqueous Solution. Journal of Geoscience and Environment Protection, 5, 138-147.

https://doi.org/10.4236/gep.2017.59010

Received: August 1, 2017

Accepted: September 8, 2017

Published: September 11, 2017

Copyright $\odot 2017$ by author and Scientific Research Publishing Inc. This work is licensed under the Creative Commons Attribution International License (CC BY 4.0).

http://creativecommons.org/licenses/by/4.0/

\begin{abstract}
The present study deals with studied the essential requirements for photo-decoulorization of nigrosine dye with suspension solution of photocatalyst ( $\mathrm{ZnO})$, under 250 Watt UV-A light $\left(I_{o}=1.47 \times 10^{-7}\right.$ ensien s$\left.^{-1}\right)$. A kinetics study of photo-decolourization for this dye was obeyed to pseudo-first order. The best initial $\mathrm{pH}$ of decolorization at $25 \mathrm{mg} / \mathrm{L}$ of dye solution with $300 \mathrm{mg}$ of $\mathrm{ZnO}$ was given a fast reaction at 8.17. The calculated activation energy for this photoreaction was found to be $31.549 \mathrm{~kJ} \cdot \mathrm{mol}^{-1}$. Thermodynamically, the reaction is exothermic and spontaneously. The efficiency of decolorizatio E\% was 97.077 at 15 min that decreased with addition oxidant reagents such as $\mathrm{H}_{2} \mathrm{O}_{2}, \mathrm{Fe}^{2+}$ and mixture from them.
\end{abstract}

\section{Keywords}

Nigreson Dye, Acid Black 2 Dye, Photocatalytic, Decolorization, Oxidant Reagents

\section{Introduction}

There are more than 100,000 varieties of dyes available in the market, which used in the textile, cosmetics, food, paper, leather industries and Medications industries. Whereas over 700,000 tons per were produced in worldwide. About $10 \%$ of the above amount of used dye is lost as wastewater, which affected on the environment by leading to Poisoning of living organisms [1] [2] [3].

During the Industrial Revolution, the synthetic dyes were quickly replaced with the commercial textiles manufactured and unlike the natural dyes, because of these dyes were suitable for synthetic fibers [4].

Nigrosin dye is a mixture of artificial black dyes (CI 50415, Solvent black 5) 
made by heating a mixture of aniline, nitrobenzene and aniline hydrochloride in found the existence of catalyst like copper or iron. The advantage of sulfonation of nigrosine dye is yielded it ability for solubling in water as anionic dye. The main industrial employed for nigrosin dye is done as a marker-pen inks and colorant for varnishes. In biology field, the nigrosin dye is employed for negative Staining bacteria, as well as the capsule-containing fungus and Cryptococcus neoformans [5] [6].

Heterogeneous photocatalysis has performed an adevastating mission technology that caused to the total mineralization of most of the organic pollutants like organic dyes. Titania $\left(\mathrm{TiO}_{2}\right)$ is the most commonly employed effective photocatalyst for a wide range of organic chemical degradation. In recent years, $\mathrm{ZnO}$ is another important semiconductor investigated. In some cases, $\mathrm{ZnO}$, has been more effective than $\mathrm{TiO}_{2}$. $\mathrm{ZnO}$ is regarded as a representative of the metal oxide class, which is played an important role to the study of electrochemistry and catalysis. The $\mathrm{ZnO}$ nanoparticle has received much attention because it has a low cost of production, responded to UV light to have a band gap range $3.2-3.3 \mathrm{eV}$, and high photoactivity in several photochemical and photoelectron-chemical processes. All these characteristic of it that lead to use it in eliminating environmental pollution [7] [8] [9] [10].

The aim of this work was focused on the studied of the effect of initial $\mathrm{pH}$, temperatures and oxidation reagent on photodecolorization of Nigresoine dye in suspension solution of $\mathrm{ZnO}$.

\section{Materials and Method}

All used chemicals in this work were employed without further purification. 99.5\% purity of commercial $\mathrm{ZnO}$ was supplied by Fluka. Nigrosin dye has molecular weight equal to $616.49 \mathrm{~g} \cdot \mathrm{mol}^{-1}$, IUPAC name is mono (4,4'-((5-phenyl-9(phenylamino) phenazine-5-ium-2,3 diyl) bis(azanediyl)) dibenzenesulfonate), synonym is Acid Black 2, molecular formula $\left(\mathrm{C}_{22} \mathrm{H}_{14} \mathrm{~N}_{6} \mathrm{Na}_{2} \mathrm{O}_{9} \mathrm{~S}_{2}\right)$, the chemical family beyonds to Aniline derivatives, classification as acid dye and supplied by High Purity Laboratory Chemicals (HPLC), Mumbai. The chemical structure for Nigrosin dye is illustrated in (Figure 1).

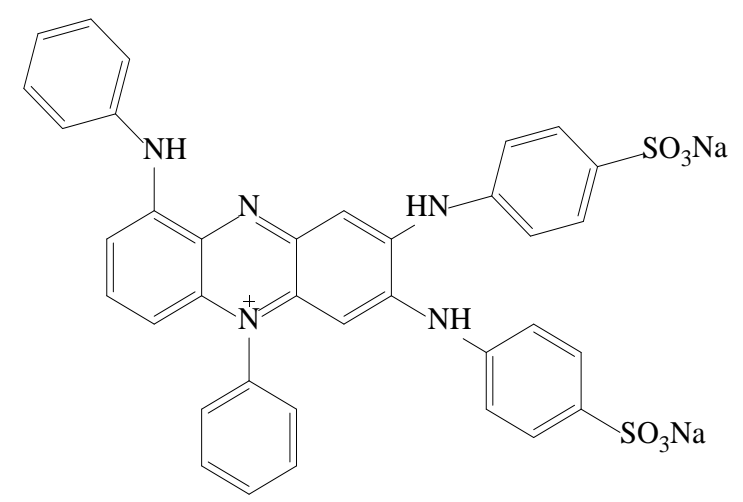

Figure 1. The chemical structure for Nigrosin dye. 
The photocatalytic decolorization by using $\mathrm{ZnO}$ experiments were done by employing home made photoreactor that consists of 250 Watt high pressure mercury lamp at light intensity $I_{o}$ equal to $1.47 \times 10^{-7}$ ensien s$^{-1}$ that calculated by chemical actinometer (ferrioxalate actinometric) [11], magnetic stirrer, wooden box that used to prevent the escape of harmful radiation [12], fan, Pyrex glass beaker and Teflon bar.

$25 \mathrm{ppm}$ of Nigrosin dye was mixed with $300 \mathrm{mg}$ of $\mathrm{ZnO}$ to generate a suspension solution by employing a magnetic stirrer. The mixing process was continued without irradiation in dark reaction for $30 \mathrm{~min}$, and then the mixture was activated via the light irradiation in photocatalytic process. About $3 \mathrm{~mL}$ of suspention solution was collected at $5 \mathrm{~min}$ as a sequence time by using a plastic test tube. The withdrawn suspention was centrifuged at $4000 \mathrm{rpm}$ for 10 minutes and filtered. The centrifuged process was repeated to ensure the completed of removing the catalyst before found the residual concentration of dye. To find the residual concentration of Nigrosin dye was measured using spectrophotometry at $570 \mathrm{~nm}$.

The rate constant for this reaction was determined by depending upon the Langmuir-Hinshelwood (L-H) model that modified to investigate the order of the studied photoreaction, from the following equations [13] [14] [15]:

$$
C_{t}=C_{o} \exp ^{\left(-k_{a p p} t\right)}
$$

where: $C_{o}$ is an initial concentration of Nigrosin dye in (dark reaction) at time of irradiation $=0, C_{t}$ is a concentration of the same dye at time $t$ of irradiation.

$$
\ln \frac{C_{o}}{C_{t}}=k_{a p p} \cdot t
$$

Equation (2) was applied, at assumption the initial concentration of dye is low, hence, the rate of photo reaction follows pseudo first-order kinetics [14]. The effeciency of decolorization $E \%$ was assessed [14] [16] in Equation (3).

$$
E \%=\frac{C_{o}-C_{t}}{C_{o}} \times 100
$$

\section{Results and Discussion}

\subsection{Effect of $\mathrm{pH}$}

The initial $\mathrm{pH}$ is regarded as a vital parameter to study the photoreaction for decolorization any dye from suspension solution of photocatalyst. The effect of $\mathrm{pH}$ from 4 to 10 on the photocatalytic decolorization of Nigrosin dye are appeared in (Figure 2(a) and Figure 2(b)) and Figure 3.

The results demonstrated that the best initial $\mathrm{pH}$ for decolorization of $\mathrm{Ni}$ grosin dye is 8.177. This value is near from the zero point charge of $\mathrm{ZnO}$ that equal to 9 [12] [17]. This effect depended upon the characteristics of studied dye, the surface charge of catalyst and generation of hydroxyl radicals via photocatalysis process [18] [19]. In acid medium, the surface of photocatalyst is positive chargly and caused photocorrosion via self oxidation, therebye the efficiency of 


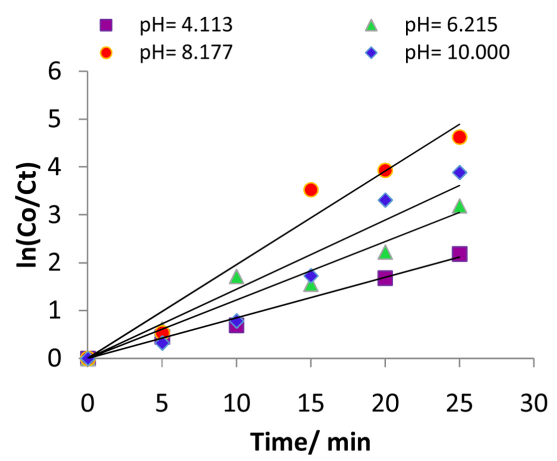

(a)

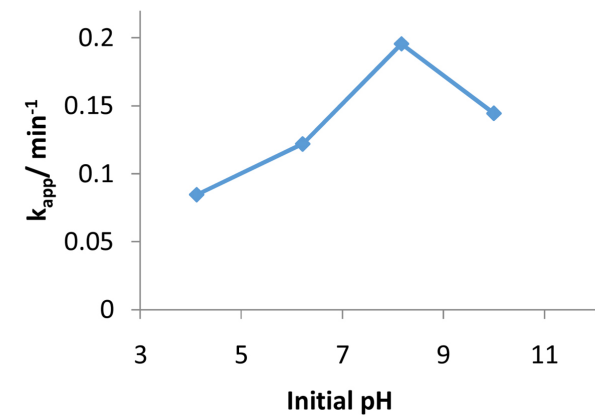

(b)

Figure 2. Effect of initial $\mathrm{pH}$ on the apparent rate constant of Nigrosin dye decolourization, dye concentration $25 \mathrm{ppm}$ with $\mathrm{ZnO}$ dosage $300 \mathrm{mg} / 100 \mathrm{~mL}$, at initial $\mathrm{pH}$ range (4.113 - 10.000), Temp. $288.15 \mathrm{~K}$ and $I_{o}$ of UV-A is $\left.1.47 \times 10^{-7} \mathrm{Ens} \mathrm{s}^{-1}\right)$. (a) $\ln \left(C_{o} / C_{t}\right)$ vs time and (b) $k_{\text {app }}$ vs initial $\mathrm{pH}$ of solution.

decolorization depresses. Moreover, In basic medium, the surface of photocatalyst is negative charge, that will lead to dissolution of the photocatalyst according to the following Equations (4)-(7) [19] [20].

$$
\begin{array}{cc}
\mathrm{ZnO}+2 \mathrm{~h}^{+} \rightarrow \mathrm{Zn}^{2+}+\frac{1}{2} \mathrm{O}_{2} \quad(\text { acidic } \mathrm{pH}) \\
\text { or } \mathrm{ZnO}+2 \mathrm{H}^{+} \rightarrow \mathrm{Zn}^{2+}+\mathrm{H}_{2} \mathrm{O} \quad(\text { acidic } \mathrm{pH}) \\
\mathrm{Zn}-\mathrm{OH}+\mathrm{OH}^{-} \rightarrow \mathrm{Zn}-\mathrm{O}^{-}+\mathrm{H}_{2} \mathrm{O} \quad(\text { basic } \mathrm{pH}) \\
\text { or } \mathrm{ZnO}+\mathrm{H}_{2} \mathrm{O}+2 \mathrm{OH}^{-} \rightarrow\left[\mathrm{Zn}(\mathrm{OH})_{4}\right]^{2-} \quad(\text { basic } \mathrm{pH})
\end{array}
$$

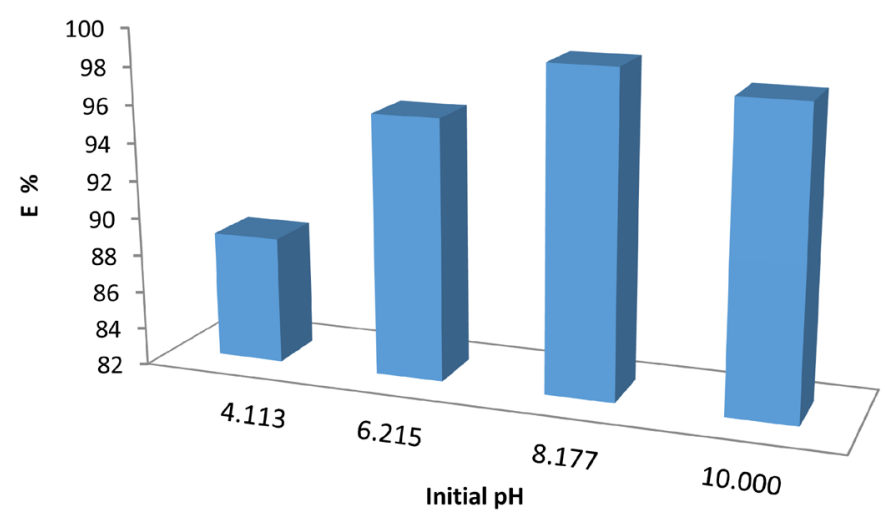

Figure 3. Effect of initial $\mathrm{pH}$ of Nigrosin dye solution on $E$ \% for decolourization of $25 \mathrm{ppm}$ from this dye with $300 \mathrm{mg} / 100 \mathrm{~mL}$ of $\mathrm{ZnO}$, at initial $\mathrm{pH}$ range (4.113 - 10.000), Temp. $288.15 \mathrm{~K}$ and $I_{o}$ of UV-A is $1.47 \times 10^{-7} \mathrm{Ens} \mathrm{s}^{-1}$ ).

Figure 3 was proved, at initial $\mathrm{pH}$ equal to 8.170 , the maximum value of the efficiency ( $E \%$ ) of removal Nigrosin dye in presence of $\mathrm{ZnO}$ is reached to 99.014 at $25 \mathrm{~min}$ and $288.15 \mathrm{~K}$.

\subsection{Effect of Temperature}

The effect of temperature on photodecolorization of Nigresone dye from sus- 
pension solution of $\mathrm{ZnO}$ was estimated in the range (283.15 - 303.15) K. This effect plays an important role to determine the apparent activation energy $\left(E_{a}\right)$ that used Arrhenius equation (Equation (8)), and some thermodynamics parameters such as $\left(\Delta H^{\#}, \Delta S^{\#}\right.$ and $\left.\Delta G^{*}\right)$ that employed Eyring-Polanyi equation (Equation (9)) and Gibbs equation (Equation (10)). These parameters were calculated by the following Equations [21] [22] [23] [24].

$$
\ln k_{\text {app }}=\frac{-E_{a}}{R T}+\ln A
$$

Whereas: $k_{\text {app }}$ is apparent rate constant, $E_{a}$ is apparent activation energy, $A$ is a frequency constant, $R$ is gas constant and $T$ is temperature of photoreaction.

$$
\ln \left(\frac{k_{a p p}}{T}\right)=\frac{-\Delta H^{\#}}{R T}+\left(\ln \frac{k_{B}}{h}+\frac{\Delta S^{\#}}{R}\right)
$$

Whereas: $k_{B}$ is a Boltzmann's constant, $h$ is a Plank's constant, $R$ is a gas constant and $T$ is the temperature of reaction.

$$
\Delta G^{\#}=\Delta H^{\#}-T \Delta S^{\#}
$$

From (Figure 4(a) and Figure 4(b)), it was observed the decolorization of the studied dye declines with increasing temperature that due to the exothermic nature in reaction $\left(\Delta H^{*}\right)$. This result is in agreement with information that reported in references [21] [25].

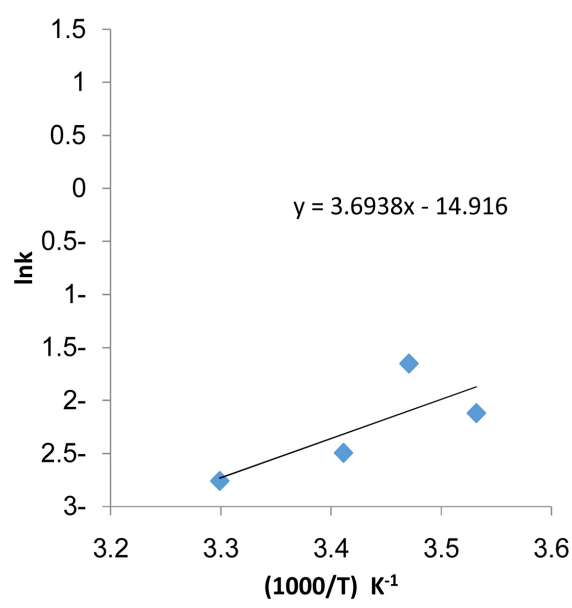

(a)

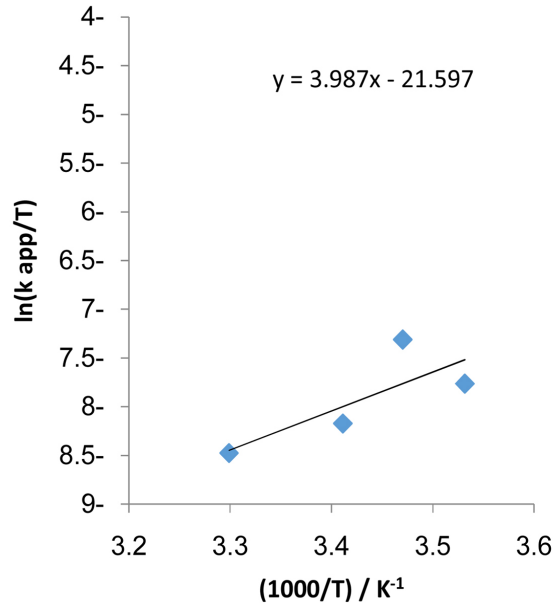

(b)

Figure 4. Effect of temperature on photodecolorization of $25 \mathrm{ppm}$ Nigresone dye, with $300 \mathrm{mg} / 100 \mathrm{~mL} \mathrm{ZnO}$, at normal initial $\mathrm{pH}$ of solution (8.177), range in temperature (283.15 - 303.15) K and $I_{o}$ of UV-A equal to $1.47 \times 10^{-7} \mathrm{Ens} \mathrm{s}^{-1}$ ). (a) Arrhenius equation plot of $(\ln k a p p)$ vs. $1 / T$. and (b) Eyring plot of $(\ln (k a p p / T))$ vs.1/T.

On basis on calculated data from Figure 4(a) and Figure 4(b), the values of activation energy and the essential thermodynamics parameters that are listed in Table 1.

The negative value of $\Delta G^{\sharp}$ for this photoreaction indicates the reaction spontaneous in nature. The negative value of $\Delta S^{\#}$ proved the depress randomness. 
Table 1. The activation kinetic and thermodynamic parameters that calculated for photodecolorisation of Nigresine dye with suspension solution of $\mathrm{ZnO}$.

\begin{tabular}{cccc}
\hline$E_{\mathrm{a}} \mathrm{kJ} \cdot \mathrm{mol}^{-1}$ & $\Delta H^{*} \mathrm{~kJ} \cdot \mathrm{mol}^{-1}$ & $\Delta S^{\sharp} \mathrm{kJ} \cdot \mathrm{mol}^{-1} \cdot \mathrm{K}^{-1}$ & $\Delta G_{303.15}^{\sharp} \mathrm{kJ} \cdot \mathrm{mol}^{-1}$ \\
\hline 30.71025 & -33.1479 & -0.00546 & -31.4927 \\
\hline
\end{tabular}

The moderate value of activation energy refer to the rate for decolorization of this dye is low and reach to final at $25 \mathrm{~min}$.

\subsection{Effect of Addition 0xidant Reagents}

Figure 5 displays the effect of addition of varies types of oxidant reagent such as $\mathrm{H}_{2} \mathrm{O}_{2}$ and $\mathrm{Fe}(\mathrm{II})$ on the decolorization of Nigrosein dye in suspension solutuion of $\mathrm{ZnO}$.

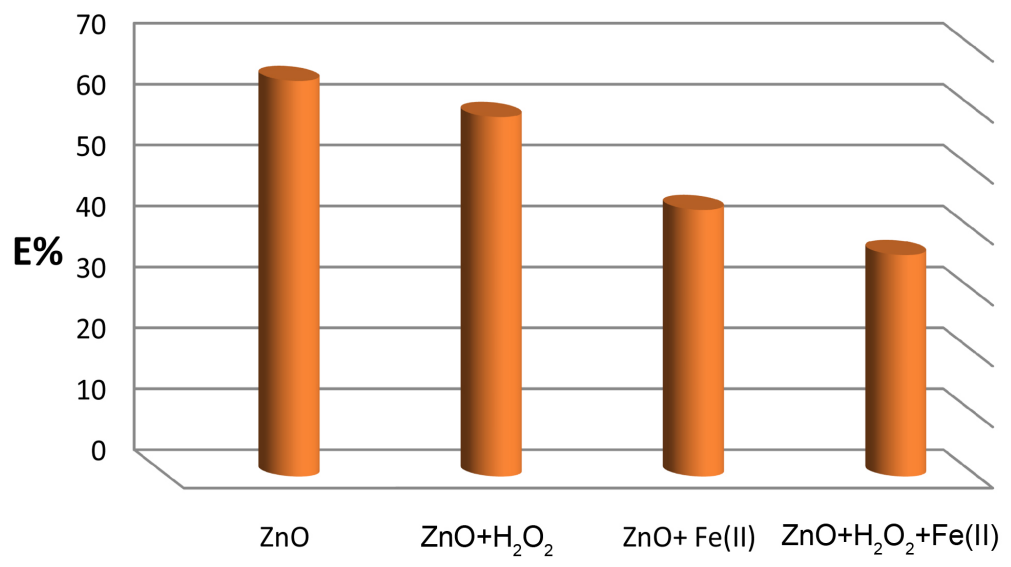

Figure 5. Effect of addition oxidant reagents on $\mathrm{E} \%$ for decolourization of 25 ppm from this dye with $300 \mathrm{mg} / 100 \mathrm{~mL}$ of $\mathrm{ZnO}$, at initial $\mathrm{pH} 8.177$, Temp. $303.15 \mathrm{~K}, 1 \% \mathrm{H}_{2} \mathrm{O}_{2}, 1 \times 10^{-4} \mathrm{M}$ Fe (II) and $I_{o}$ of UV-A is $1.47 \times 10^{-7} \mathrm{Ens} \mathrm{s}^{-1}$ ).

In case of used $\mathrm{ZnO}$ alone as photocatalyst, The $\mathrm{E} \%$ for decolorization of above-mentioned dye is equal to 64.9122 at $30^{\circ} \mathrm{C}$ (Lab temperature) and $15 \mathrm{~min}$. The hydroxyl radical acts as a power for starting the photoreaction with presence of photocatalyst. This progress of photoreaction was monitored by the following equations [26] [27].

$$
\begin{gathered}
\mathrm{ZnO}+h v \rightarrow \mathrm{ZnO}\left(\mathrm{e}_{\mathrm{CB}}^{-}+\mathrm{h}_{\mathrm{VB}}^{+}\right) \\
\mathrm{H}_{2} \mathrm{O}+\mathrm{h}_{\mathrm{VB}}^{+} \rightarrow \mathrm{H}^{+}+\mathrm{HO}^{\cdot} \\
\mathrm{O}_{2}+\mathrm{e}_{\mathrm{CB}}^{-} \rightarrow \mathrm{O}_{2}^{--} \\
\mathrm{O}_{2}^{--}+\mathrm{H}^{+} \rightarrow \mathrm{HO}_{2}^{-} \\
\mathrm{HO}_{2}^{-}+\mathrm{H}^{+} \rightarrow \mathrm{H}_{2} \mathrm{O}_{2} \\
\mathrm{H}_{2} \mathrm{O}_{2}+h v \rightarrow 2 \mathrm{HO}^{\circ}
\end{gathered}
$$

The decolorization of Nigresine dye will suggest in the following equation

$$
\text { Dye }+\mathrm{HO}^{*} \rightarrow n \mathrm{CO}_{2}+n \mathrm{H}_{2} \mathrm{O}+\text { Inorganic ions }\left(\mathrm{NH}_{4}^{+}, \mathrm{SO}_{4}^{2-}+\mathrm{Na}^{+}\right)
$$


When addition $1 \%$ of $\mathrm{H}_{2} \mathrm{O}_{2}$ to suspension solution of dye and $\mathrm{ZnO}$, that depress the $\mathrm{E} \%$ to 58.969 , that attributable to the high concentration of $\mathrm{H}_{2} \mathrm{O}_{2}$ that acts as scavenger for $\bullet \mathrm{OH}$ radical to form Perhydroxyl radical $\mathrm{HO}_{2}^{\cdot}$ [12] [26].

$$
\begin{gathered}
\mathrm{H}_{2} \mathrm{O}_{2}+\mathrm{HO}^{\circ} \rightarrow \mathrm{H}_{2} \mathrm{O}+\mathrm{HO}_{2}^{\cdot} \\
\mathrm{HO}_{2}^{-}+\mathrm{HO}^{-} \rightarrow \mathrm{H}_{2} \mathrm{O}+\mathrm{O}_{2}
\end{gathered}
$$

In this work, the process for addition of Fe(II) in concentration $1 \times 10^{-4} \mathrm{M}$ to the dye solution with presence $\mathrm{ZnO}$ has a negative effect. So, $E \%$ of this reaction declines to be 43.750 . That belongs on the reacted of $\mathrm{Fe}^{2+}$ with Perhydroxyl radical, according to the following equation [28] [29].

$$
\begin{gathered}
\mathrm{HO}_{2}^{-}+\mathrm{Fe}^{2+} \rightarrow \mathrm{HO}_{2}^{-}+\mathrm{Fe}^{3+} \\
\mathrm{HO}_{2}^{-}+\mathrm{Fe}^{2+} \rightarrow \mathrm{O}_{2}+\mathrm{Fe}^{3+}+\mathrm{H}^{+}
\end{gathered}
$$

From the other hand, the used of fenton's reaction in the conditions of the photoreaction, that leads to depress the $E \%$ to 36.363 . The certain concentration of $\mathrm{H}_{2} \mathrm{O}_{2}$ and $\mathrm{Fe}^{2+}$ causes to produce $\mathrm{H}_{2} \mathrm{O}$ and $\mathrm{O}_{2}$ [30] [31].

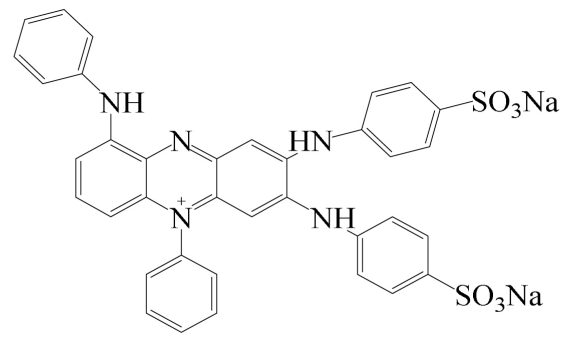

disodium mono(4,4'-((5-phenyl-9-(phenylamino)phenazine-5-ium-2,3diyl)bis(azanediyl))dibenzenesulfonate)

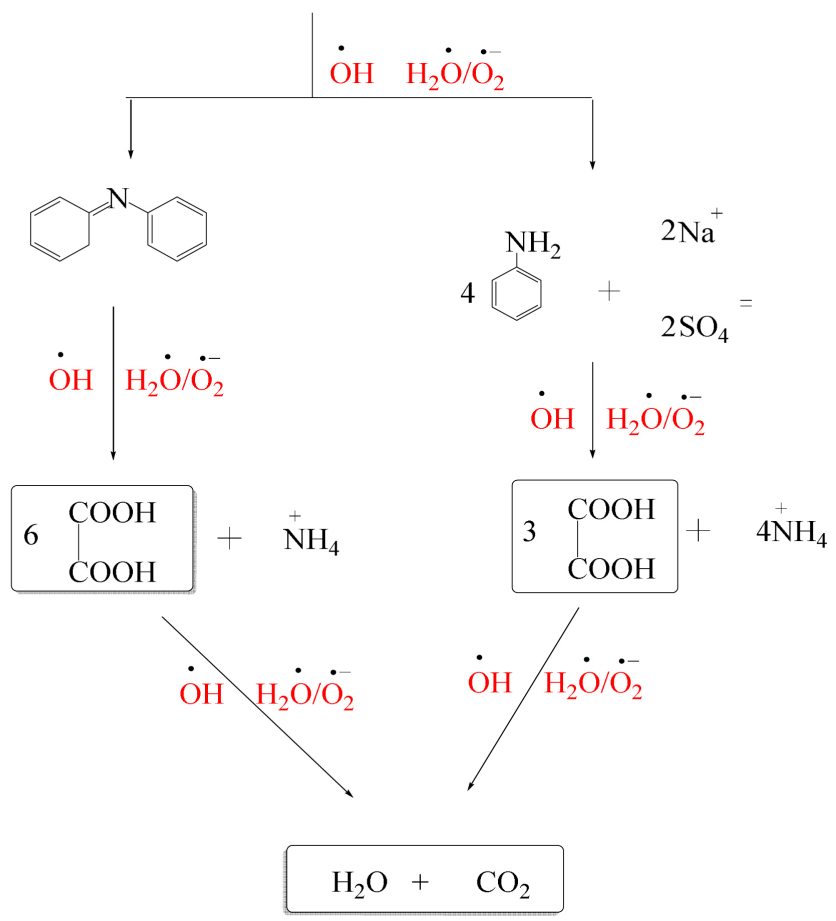

Scheme 1. Suggested mechanism for decolorization of Negrisone in suspension solution of $\mathrm{ZnO}$. 


$$
\begin{gathered}
\mathrm{Fe}^{2+}+\mathrm{H}_{2} \mathrm{O}_{2} \rightarrow \mathrm{Fe}^{3+}+\mathrm{HO}^{\cdot}+\mathrm{HO}^{-} \\
\mathrm{H}_{2} \mathrm{O}_{2}+\mathrm{HO}^{\cdot} \rightarrow \mathrm{H}_{2} \mathrm{O}+\mathrm{HO}_{2}^{\cdot} \\
\mathrm{HO}_{2}^{\cdot}+\mathrm{HO}^{\cdot} \rightarrow \mathrm{H}_{2} \mathrm{O}+\mathrm{O}_{2}
\end{gathered}
$$

\subsection{Proposed Mechanism}

The suggested mechanism for decolorization of Nigreson in presence $\mathrm{ZnO}$ under UV-A light was summarized in (Scheme 1).

\subsection{Conclusions}

The essential conclusions for this work were proven the following results:

1) The photoreaction of decolorization of Nigresoin dye in suspension solution of $\mathrm{ZnO}$ obeys the pseudo first order kinetics.

2) The Rate of photocatalytic decolorization of the above dye is followed the next sequences:

Rate of decolorization in presence $\mathrm{ZnO}$ alone $>$ Rate of decolorization in presence $\mathrm{ZnO}$ with $\mathrm{H}_{2} \mathrm{O}_{2}>$ Rate of decolorization in presence $\mathrm{ZnO}$ with $\mathrm{Fe}(\mathrm{II})>$ Rate of decolorization in presence $\mathrm{ZnO}$ with $\mathrm{H}_{2} \mathrm{O}_{2}$ and $\mathrm{Fe}(\mathrm{II})$.

3) The decolorization reaction is fast, exothermic and spontaneously at initial pH 8.177 of dye solution.

4) At $25 \mathrm{~min}$ and $288.15 \mathrm{~K}$, the efficiency ( $E \%$ ) of removal Nigrosin dye in presence of $\mathrm{ZnO}$ was reached to maximum value and to be 99.014 .

\section{References}

[1] Babič, J. and Pavko, A. (2007) Production of Ligninolytic Enzymes by Ceriporiopsis Subvertmispora for Decolourization of Synthetic Dyes. Acta Chimica Slovenica, 54, 730-734.

[2] Blanquez, P., Casas, N., Font, X., Gabarrell, X., Sarra, M., Caminal, G. and Vicent (2004) Mechanism of Textile Metal Dye Biotransformation by Trametes versicolor. Water Research, 38, 2166-2172.

[3] Borchert, M. and Libra, J.A. (2001) Decolorization of Reactive Dyes by the White Rot Fungus Trametes versicolor in Sequencing Batch Reactors. Biotechnology and Bioengineering, 3, 312-321.

[4] Kakhia, T.I. (2015) Dyes, Colors \& Pigments. http://tarek.kakhia.org

[5] Green, F.J. (1990) The Sigma-Aldrich Handbook of Dyes, Stains and Indicators. Aldrich, Milwaukee, 513-515.

[6] Clark, G. (1981) Staining Procedures Used by the Biological Stain Commission. 4th Edition, Williams \& Wilkins, Baltimore, London, 412.

[7] Linsebigler, A.L., Lu, G.Q. and Yates, J.T. (1995) Photocatalysis on $\mathrm{TiO}_{2}$ Surfaces: Principles, Mechanisms, and Selected Results. Chemical Reviews, 95, 735-758. https://doi.org/10.1021/cr00035a013

[8] Duxbury, D.F. (1993) The Photochemistry and Photophysics of Triphenylmethane Dyes in Solid and Liquid Media. Chemical Reviews, 93, 381-433. https://doi.org/10.1021/cr00017a018

[9] Hoffman, M.R., Martin, S.T., Choi, W. and Bahnemann, W. (1995) Environmental 
Applications of Semiconductor Photocatalysis. Chemical Reviews, 95, 69-96. https://doi.org/10.1021/cr00033a004

[10] Kandavelu, V., Kastien, H. and Thampi, K.R. (2004) Photocatalytic Degradation of Isothiazolin-3-Ones in Water and Emulsion Paints Containing Nanocrystalline $\mathrm{TiO}_{2}$ and $\mathrm{ZnO}$ Catalysts. Applied Catalysis B: Environmental, 48, 101-111. https://doi.org/10.1016/j.apcatb.2003.09.022

[11] Ahmed, S. (2004) Photo Electrochemical Study of Ferrioxalate Actinometry at a Glassy Carbon Electrode. Journal of Photochemistry and Photobiology A: Chemistry, 161, 151-154.

[12] Mashkour, M.S., Al-Kaim, A.M., Ahmed, L.M. and Hussein, F.H. (2011) Zinc Oxide Assisted Photocatalytic Decolorization of Reactive Red 2 Dye. International Journal of Chemical Sciences, 9, 969-979.

[13] Eesa, M.T., Juda, A.M. and Ahmed, L.M. (2016) Kinetic and Thermodynamic Study of the Photocatalytic Decolourization of Light Green SF Yellowish (Acid Green 5) Dye using Commercial Bulk Titania and Commercial Nanotitania. International Journal of Science and Research, 5, 1495-1500.

[14] Giwa, A., Nkeonye, P.O., Bello, K.A., Kolawole, E.G. and Oliveira Campos, A.M.F. (2012) Solar Photocatalytic Degradation of Reactive Yellow 81 and Reactive Violet 1 in Aqueous Solution Containing Semiconductor Oxides. International Journal of Applied Science and Technology, 2, 90-105.

[15] Fatha, E.S. and Ahmed, L.M. (2015) Optimization of Photocatalytic Decolorization of Methyl Green Dye Using Commercial Zinc Oxide as Catalyst. Kerb Journal, 13, 53-63.

[16] Hassena, H. (2016) Photocatalytic Degradation of Methylene Blue by Using $\mathrm{Al}_{2} \mathrm{O}_{3} / \mathrm{Fe}_{2} \mathrm{O}_{3}$ Nano Composite under Visible Light. Modern Chemistry \& Applications, 4, 1-5.

[17] Khodja, A., Sehili, A.T., Pilichowski, J. and Bolue, P. (2001) Photocatalytic Degradation of 2-Penylphenol on $\mathrm{TiO}_{2}$ and $\mathrm{ZnO}$ in Aqueous Suspensions. Journal of Photochemistry and Photobiology A: Chemistry, 141, 231-239.

[18] Byrappa, K., Subramani, A., Ananda, S., Rai, K., Dinesh, R. and Yoshimura, M. (2006) Photocatalytic Degradation of Rhodamine B Dye Using Hydrothermally Synthesized ZnO. Bulletin of Materials Science, 29, 433-438. https://doi.org/10.1007/BF02914073

[19] Ahmed, L.M., Tawfeeq, F.T., Abed Al-Ameer, M.H., Abed Al-Hussein, K. and Athaab, A.R. (2016) Photo-Degradation of Reactive Yellow 14 Dye (A Textile Dye) Employing $\mathrm{ZnO}$ as Photocatalyst. Journal of Geoscience and Environment Protection, 4, 34-44. https://doi.org/10.4236/gep.2016.411004

[20] Nadjia, L., Abdelkader, E. and Ahmed, B. (2011) Photodegradation Study of Congo Red in Aqueous Solution using $\mathrm{ZnO} / \mathrm{UV}-\mathrm{A}$ : Effect of $\mathrm{pH}$ and Band Gap of Other Semiconductor Groups. Journal of Chemical Engineering and Process Technology, 2, 1-9. https://doi.org/10.4172/2157-7048.1000108

[21] Qadri, M., Nisar, S. and Fatima, N. (2015) Photokinetics of the Oxidation of Coomassie Brilliant Blue by Potassium Dichromate in Acidic Medium. International Journal of Advanced Research, 3, 888-898.

[22] Olajire, A.A. and Olajide, A.J. (2014) Kinetic Study of Decolorization of Methylene Blue with Sodium Sulphite in Aqueous Media: Influence of Transition Metal Ions. Physical Chemistry \& Biophysics, 4, 1-7.

[23] Ahmed, L.M., Mahdi, Q.M., Mahmoud, F.S., Mahammed, M.J. and Ahmed, N.S. (2017) Kinetic Study for the Decolorization of Dispersive Blue 26 Dye from Suspen- 
sion Solution of Commercial ZnO. The 5 th Scientific Conference of the College of Science University of Kerbala, 127-136.

[24] Tabbara, M.A. and Jamal, M.M. (2012) A Kinetic Study of the Discoloration of Methylene Blue by $\mathrm{Na}_{2} \mathrm{SO}_{3}$, Comparison with $\mathrm{NaOH}$. Journal of the University of Chemical Technology and Metallurgy, 47, 275-282.

[25] Goharshadi, E.K., Hadadian, M., Karimi, M. and Azizi-Toupkanloo, H. (2013) Photocatalytic Degradation of Reactive Black 5 azo Dye by Zinc Sulfide Quantum Dots Prepared by a Sonoch-Emical Method. Materials Science in Semiconductor Processing, 16, 1109-1116.

[26] Hussein, F.H. (2012) Photochemical Treatments of Textile Industries Wastewater. Asian Journal of Chemistry, 24, 5427-5434.

[27] Yatmaz, H.C., Akyol, A. and Bayramoglu, M. (2004) Kinetics of the Photocatalytic Decolorization of an Azo Reactive Dye in Aqueous $\mathrm{ZnO}$ Suspensions. Industrial \& Engineering Chemistry Research, 43, 6035-6039. https://doi.org/10.1021/ie049921z

[28] Malik, P.K. and Saha, S.K. (2003) Oxidation of Direct Dyes with Hydrogen Peroxide using Ferrous Ion as Catalyst. Separation and Purification Technology, 31, 241-250.

[29] Akash, T. and Gidde, M.R. (2014) Decolourization of Nigrosine WS (AB2) Dye by Solar Photo-Fenton Process. The International Journal of Science \& Technology, 2, 68-73.

[30] Jr, A.M., Quina, F.H., Gozzi, F., Silva, V.O., Friedrich, L.C. and Moraes, J.E.F. (2012) Fundamental Mechanistic Studies of the Photo-Fenton Reaction for the Degradation of Organic Pollutants. In: Puzyn, T., Ed., Organic Pollutants Ten Years after the Stockholm Convention Environmental and Analytical Update, InTech.

[31] Petri, B.G., Watts, R.J., Teel, A.L., Huling, S.G. and Brown, R.A. (2011) Fundamentals of Isco Using Hydrogen Peroxide. In: Siegrist, R.L., Crimi, M. and Simpkin, T.J., Eds., In Situ Chemical Oxidation for Groundwater Remediation, Springer, Berlin.

\section{Submit or recommend next manuscript to SCIRP and we will provide best service for you:}

Accepting pre-submission inquiries through Email, Facebook, LinkedIn, Twitter, etc. A wide selection of journals (inclusive of 9 subjects, more than 200 journals)

Providing 24-hour high-quality service

User-friendly online submission system

Fair and swift peer-review system

Efficient typesetting and proofreading procedure

Display of the result of downloads and visits, as well as the number of cited articles

Maximum dissemination of your research work

Submit your manuscript at: http://papersubmission.scirp.org/

Or contact gep@scirp.org 